${ }^{1}$ Groupe de recherche sur la santé des adolescents, Institut universitaire de médecine sociale et préventive, Université de Lausanne, Switzerland

${ }^{2}$ Department of Paediatrics \& Adolescent Medicine, Tbilisi State Medical University of Georgia

${ }^{3}$ Research Group on Children \& Adolescent Health \& Development, Institute of Medical Biotechnology, Academy of Sciences of Georgia

\title{
The Georgian Adolescent Health Survey: methodological and strategic issues
}

\author{
Submitted: 12 November 2003 \\ Accepted: 5 April 2005
}

Summary

Objectives: To conduct a national survey on adolescent health and lifestyles in Georgia and to thus set up a database on adolescent.

Methods: A two-stage cluster sample of around 8000-10000 in-school 15-18 years adolescents are being reached through a random selection of classes in Georgia. The sample has been stratified by age, region, type of school and language. A self-administered questionnaire of 87 questions has been developed and translated into the four main languages used in Georgia.

Results: Up to June 2004, the researchers have reached 511 classes (9306 pupils). In total, 8039 questionnaires have been considered valid. The main concerns encountered for this survey are linked with acceptance of the survey, cross-cultural issues, political and strategic problems as well as inadequate physical environmental support.

Conclusion: Despite Georgia's unfavourable economical and political situation, it has been possible to run a national survey on the health of adolescents, according to the usual standards used in the field. This survey should allow for 1) the identification of priorities in the field of health care and health promotion 2) the monitoring of adolescent health in the future.

Keywords: Adolescent - Survey - Health - Methods - Eastern Europe - Georgia.

Georgia, a country of about 5.5 million inhabitants, is made up of various provinces with their specific cultural background and characteristics. Even though this country has recently witnessed a major change in its political system (November 2003), according to neutral observers, the capital, Tbilisi, has still no good control over many parts of the provinces of Abkhazeti and South Oseti (Tskhinvali region). The great majority of the country population are Georgians, but there are also minorities speaking other languages, the most important ones being Russian, Armenian and Azerbaijani (each spread in approximately $5 \%$ of schools). During the last 12 years, Georgia has been going through a quasi-natural experiment with a huge transition from a planned economy to a market economy, jeopardizing economical liaisons and leading to ethnic conflicts, increased criminality, and pauperisation. About $20 \%$ of population has emigrated or been displaced for economical and/or safety reasons. In this context of uncertainty about the future prospect, the health of the population and particularly the one of adolescents is heavily menaced.

Until recently, like in other ex-Soviet countries, adolescent medicine and health was never tackled as such at the medical universities in Georgia. In 1996, the Department of Paediatrics of Tbilisi State Medical University was renamed into the Department of Paediatrics and Adolescent Medicine. Accordingly, members of its staff currently work on improving the training at pre and post-graduate level in this field and are developing research activities specifically directed at the health of teenagers (Pagava et al. 2001). Apart from this initiative - located in the capital only - there have been few efforts to date to address the issue of adolescent health care in a global, country-level, public health perspective. To design sound policies and interventions directed at young people and monitor them in the future, health authorities do need data on the current state of health and lifestyles of teenagers. At present these data are fragmentary and scrappy (Pagava 2004).

This project is a joint research project undertaken within the frameworks of the SCOPES program of the Swiss National Science Foundation (www.snf.ch). The main goal of the project is to gather representative data on adolescent health 
in Georgia which should allow for the choice of priorities, the planning and implementation of effective health care and prevention structure as well as the monitoring of adolescent health in the future. Moreover, it should promote the transfer to a team of Georgian researchers of the knowledge and skills for designing, implementing and exploiting adolescent health surveys. The objectives of this paper are to describe the design and implementation of this first Georgian survey on adolescent health and to highlight the strategic issues that have arisen during this process.

\section{Methods}

\section{Survey design and timeframe}

The "Groupe de recherche sur la santé des adolescents", located at the Institute for Social and Preventive Medicine in Lausanne is working since about 10 years in the field of adolescent health (Narring \& Michaud 1995; Narring et al. 1994) and since two years, has designed and run a national survey on the health and lifestyles of adolescents aged 16 to 20 years (Narring et al. 2003). This group has set up over the last five years a group of European experts in the field of adolescent health and medicine which has developed a training curriculum called EuTEACH (standing for European Training in Effective Adolescent Care and Health (Michaud et al. 2004) and to which one of the authors (KP), professor of paediatrics and adolescent medicine in Tbilisi, Georgia, belongs. It is within this "think tank" group that the usefulness of a collaboration on adolescent health survey has emerged. As a first step, two authors (PAM \& KP) discussed the feasibility of such a survey and then designed the grant proposal to the SNSF. In September 2002, one of the authors (PAM) spent a one-week stay in Tbilisi with the research team followed by a second stay of another Swiss researcher in Georgia (AJ) and recently a stay of a member of the Georgian team (HP) in Lausanne.

Several possible methods for gathering self-reported data on the health of the Georgian youth population were considered. The first one was running individual interviews, usually at home; this is reliable method but extremely expensive if one wants to cover several 100 of individuals and was thus considered as unaffordable in the context of Georgia. The second was the use of CATI (computer-assisted telephone interviews), a method which is used since several years by the CEFS/INPES in France for the gathering of health data both in the general and adolescent population (so-called "baromètre santé" (Arènes et al. 1998)). However, there is a low rate of households equipped with a phone in Georgia, especially in the rural regions where some areas are completely without any fixed phone connection and although mobile phones are available in large cities, there are no data on the extent to which young people can be reached through this channel. Postal survey was also excluded because of the unreliability of the postal delivery system across the country, as was Internet survey due to access being available practically only in the capital. There are however good data on the organisation of school services in the country and this was the easiest possible way to construct a proper sampling frame. It was thus decided, as in many other instances (Choquet \& Ledoux 1994; Currie et al. 2004; Resnick et al. 1997; Schmid 2003), to rely on a paper and pencil self-administered questionnaire distributed within the education system.

The Swiss team had similarly used a self-administered questionnaire to run the Swiss adolescent survey (Narring \& Michaud 1995) and as such, this instrument was a good starting point for the design of the Georgian questionnaire, knowing that some adaptation of content and formulation would be necessary. Moreover, it was felt that the similarity between the Swiss and Georgian questionnaire would allow for comparative analyses run by the two teams in close collaboration (Michaud et al. 2001). The planning and implementation of the survey followed the standard strategic and ethical recommendations in the field (Arènes et al. 1998; Coughlin \& Beauchamp 1992; Currie et al. 2004; Lothen-Kline et al. 2003; Miller 1991; Narring et al. 2003; Statistics Canada 1996), as described below.

The project started in May 2002. A multi-annual time frame was developed: a first stage which was planned to last 12 months was dedicated to the preliminary work focusing on translation and adaptation of the questionnaire in parallel with contacting the central political and administrative authorities in Tbilisi and in the regions; this process took longer than expected. During that period, the Lausanne team was developing the sampling plan based on school and class lists provided by the Georgian team; a second stage (six months) was dedicated to the fieldwork (data gathering); this step took also much more time than expected due to political problems in remote parts of the country. Thirdly, more than the expected six months were is used for data entry and production of the SPSS data file, due to electric breakdowns and lack of heating; the cleaning of a first dataset (5000 questionnaires) and preliminary analyses are performed currently. A final stage of unspecified duration will be used for the dissemination of the results in the country as well as the publication of basic and specific papers, both in Georgian and international journals.

\section{The questionnaire}

The original Swiss "SMASH-2002" questionnaire (available on request in French, German and Italian at www.umsa.ch) is 
a self-administered anonymous form comprised of 565 items (93 questions) which builds upon the 1993 SMASH survey as well as upon the large body of research made on adolescent health during the last decade (Arènes et al. 1998; Choquet et al. 1992; Choquet \& Ledoux 1993; Schmid 2003; Zimmer-Gembeck et al. 1997), including the well-known Health Behaviour of School Children survey sponsored by the World Health Organisation (Currie et al. 2004). The framework leading to the choice of various indicators and variables has been described earlier (Narring \& Michaud 1995; Narring et al. $2003 ;$ 1994). The questionnaire focuses on adolescent health and lifestyles incorporating both risk factors and resources on the personal and environmental levels (Tab. 1).

\section{Adaptation of the questionnaire}

As a first step, the questionnaire was translated into Georgian from the German and French versions and then translated from Georgian into English to test for accuracy. It was then translated in the three other languages most often used in minorities in Georgia - Russian, Armenian and Azeri - and then back translated into Georgian.

It was very important to check the appropriateness of the design, content and wording of the questionnaire with Georgian adolescents themselves. A fruitful approach to pre-test a questionnaire is to set-up focus groups of adolescents where participants fill out the questionnaire and discuss its content and main issues using a structured list of questions (Michaud et al. 2001; Spruijt-Metz 1999). Five focus groups of around 8-12 adolescents were run: Two groups came from a medical college, two others from classes of a secondary school and one last group was set up through informal snow-ball recruitment. All the groups were located in Tbilissi. Four groups were run in Georgian, one in Russian. The two hours sessions focused on the content of the questionnaire, the wording of the questions, and the degree to which it was acceptable to young people. A similar discussion was run with representatives of the Youth Parliament of Georgia. The questionnaire was then presented to various political, administrative and social (e.g. parents committee) bodies in charge of the authorisation of such a survey.

Following their comments and those from the focus groups, some questions pertaining to sexuality were taken out and the sexuality module was moved to the end of the questionnaire. However, all questions on substance use were kept. Questions on the ethnic status of the respondents have been worded according to the local situation. For instance, taking into account the current political climate, an additional modality (Abkhazian) has been added to the nationality question despite the fact that this region of the Georgia is not administratively considered as a distinct nationality.
An important step was to submit the questionnaire for final approval to the following authorities and organizations, including: Councils of Ministry of Labour, Health, Social Affairs and Education, the State Department for The Youth Affairs, parents Council, representatives from the Youth Parliament and the church. The final version includes 87 questions (556 items) and is very similar to the Swiss version with the exception of the censored sexual matters.

\section{Sampling}

It was difficult to assess exactly the percentage of young people aged 15-18 years (the target population) who still attend school. Local experts (representatives of Ministry of Education, teachers, adolescent physicians) were consulted. Based on their suggestions, it was decided to focus on the adolescents spending most of their time in schools since about $70-75 \%$ of this age group regularly attend school. In Georgia, there are various types of schools providing mandatory secondary education, various technical skills or preparation for further higher education. A two-stage cluster sampling was devised. A sampling frame was made of the list of all classes of grade 9 to 11 in the entire country accommodating for teenagers aged 15-18 years. This list was provided by the Ministry of Education and was then verified in each region. The final list comprised 8759 classes with information on language, region, type of school and grade. Due to the fact that South Ossetia (Tskhinvali region) and Abkhazia are de facto outside Georgian jurisdiction, this list did not contain the classes from these regions themselves, but rather the classes elsewhere in Georgia where the majority of displaced children from these regions are taught under jurisdiction of the displaced official administrations of these regions. The sample has been stratified accordingly. A random iterative cluster sample of classes as primary sampling units was drawn by a statistician of the Lausanne team, with adjusted weighting of some regions and languages other than Georgian. Regions and types of schools were treated as strata: Sampling weights were increased for the Abkhazeti region (by a factor of 5), for the Ambrolauri/Lentekhi/Oni region (factor of 2), as well as for the Armenian (factor of 2), Azerbaijan (factor of 3) and Russian (factor of 3) speaking populations. Schools offering only one or two grades instead of three were down weighted by a factor of 20 and 10 respectively. The target sample size of 10000 pupils included an increase of $15 \%$, in order to cover potential defections of schools or classes(Statistics Canada 1996). A total of 599 classes were selected, yielding a sampling fraction of classes of $6.84 \%$.

\section{Fieldwork}

Fieldwork was performed under the supervision of the research team: health professionals working in the area of 
adolescent medicine and health as well as medical students have been trained to distribute the questionnaire in the classes using a uniform procedure: standardized introduction (aim of the survey, importance of adherence of young people to the project), ethical aspects (subjects free not to answer, anonymity), information on where to go for further counselling or health care. Due to the fact that, in some parts of the country, representatives from the capital are ill accepted if not totally rejected, it was very important to identify and involve local collaborators to assure the best possible acceptance of the questionnaire. Consequently, in remote parts of Georgia, the questionnaire was distributed by local health professionals. Teachers were not present in the classrooms during the completion of the questionnaires ( 2 periods, $\sim 1 \frac{1}{2}$ hour available).

Before being processed for data entry, all questionnaires were edited according to written instructions (Sonquist \& Dunkelberg 1977): editing of contradictory or missing information, translation of comments and text answers from Georgian, Russian, and Azeri into English, transcription of information difficult to read. Other comments made by the pupils were saved into a separate file. Editors were instructed to write down any personal decision not covered by the instructions. In addition, editors were asked to rate the validity of every questionnaire from 1 to 3 (1: few or no problems, 2: some problems, 3: many problems).

Data entry operators have been selected and trained locally, and have received written instructions. The EpiData program allows for an easy data entry and a continuous checking of the quality of the data entry process.

\section{Logistics}

The acquisition of processing and electronic equipments (computers, SPSS program) have been included in the budget of the project, since no computing infrastructure was available locally. One desktop computer and one laptop with a modem for internet connection through telephone lines were bought. Moreover, PHProjekt (www.phprojekt.com), a free, open-source groupware application, was used for the coordination of the team activities and for easy and continuous sharing of information between Lausanne and Tbilisi. PHProjekt runs on any internet browser and does not require any specific installation on the local computer; it only needs installation on a internet-connected server; in our case, this was done at Lausanne University. The freeware programme EpiData (www.epidata.dk) was used for data entry. It was chosen because, in addition to being free, it implements very well the requirements for the entry of survey data (Bennett et al. 2004): checks on the permitted values, very good manual stressing safety issues, user-friendly interface, good export
Table 1 Main topics covered in the Georgian survey

\begin{tabular}{|c|c|c|}
\hline \multirow[t]{2}{*}{ Health determinants } & \multicolumn{2}{|l|}{ Outcomes } \\
\hline & Health status & Health behaviours \\
\hline socio-demogr. & reported health needs & reported health \\
\hline $\begin{array}{l}\text { characteristics } \\
\text { cultural context, } \\
\text { education }\end{array}$ & & $\begin{array}{l}\text { behaviour: } \\
\text { use of psycho active } \\
\text { substance }\end{array}$ \\
\hline migration & & violence \\
\hline connectedness & & eating patterns, \\
\hline $\begin{array}{l}\text { personal resources } \\
\text { coping styles }\end{array}$ & $\begin{array}{l}\text { reported physical } \\
\text { health status }\end{array}$ & $\begin{array}{l}\text { reported preventive } \\
\text { behaviour }\end{array}$ \\
\hline $\begin{array}{l}\text { environmental. } \\
\text { resources }\end{array}$ & & $\begin{array}{l}\text { leisure activities } \\
\text { sports activities }\end{array}$ \\
\hline risk factors & reported mental health & $\begin{array}{l}\text { reported health } \\
\text { care seeking }\end{array}$ \\
\hline risk taking & chronic condition & use of medication \\
\hline lifestyles & functional limitations & \\
\hline $\begin{array}{l}\text { beliefs and future } \\
\text { expectation }\end{array}$ & & \\
\hline
\end{tabular}

capabilities to various statistical packages. It also makes it easy to perform regular backups of the processed data. The SPSS v11.0 was used for statistical data analysis. jEdit (www.jedit.org), an open-source multi-purpose editor, was being used for writing SPSS syntax files. A total amount of around 50000 CHF (40000 USD) has been made available by the Swiss National Foundation and has indeed covered the travels to and from Georgia and stay accommodation, the acquisition of the electronic devices and programs, the printing of the questionnaires, the transfer on the dataset and the salary of some of the researchers as well as the travels of the field collaborators. According to the SCOPES financial framework, the Lausanne team has worked for free.

\section{Ethical considerations}

Ethical and legal requirements for collecting data in an adolescent population were taken into account (Coughlin \& Beauchamp, 1992; Lothen-Kline et al. 2003; Narring \& Michaud 1995; Narring et al. 1994). The participation in the survey was absolutely voluntary and the questionnaires were anonymous. Participants were informed on the aim of the study and on the fact that this survey was completely independent from school. Field workers distributing the questionnaires within the classes were able to supply adolescents with appropriate addresses and guidance in case of need. When the final results will be available, the research team will make every effort to disseminate a summary among participating schools. The original SMASH survey had been submitted to the Ethical commission of the Faculty of Medicine in Lausanne; the Georgian survey was submitted to the Bioethical commission of the Ministry of Labour, Health and Social Affairs of Georgia. 


\section{Progress of the survey}

Field workers had an official letter of The Ministry of Education addressed to all regional and local education authorities, which made the task easier in some hesitating schools. However, six from 172 schools have refused to participate mainly as a result of the headmaster's decision. The formal reason given was that some they didn't want to submit questions regarding gender-specific physiology to their pupils. This occurred despite the fact that according to the recommendations of the Ministry of Education, the number of such questions had been substantially reduced. The research team's opinion is that a reluctance to give information about teachers-pupils relations in these schools did play a role.

Although there are no precise data available, it is estimated that $10-15 \%$ of young people aged $15-18$ years have left school, more girls than boys: in some rural areas where the majority of population is Muslim, girls tend to leave school before grade 10 or 11 due to a tradition of early marriage.

Within the selected classes, only about $0.5 \%$ of pupils refused to participate. Up to June 2004, the researchers have reached 511 classes and gathered more than 9000 questionnaires, of which $80 \%$ were found to raise few or no problems, $19 \%$ to raise some problems; around $1.0 \%$ were found to be unusable. In total, 8038 have been considered valid. Based on this number, the survey appears to have been well accepted and to yield good quality data. Table 2 presents some socio-demographic characteristics of the sample as it stands in March $2005^{1}$, compared with some data from the Georgian 2000 census. It shows that the sample, as far as these characteristics are concerned, is fairly representative of the general population of Georgia in terms of ethnicity and residence. There are many more girls than boys in this sample. One reason for this is that more boys than girls tend to miss school because they are engaged in various jobs to earn money. Another hypothesis is that among the 400 respondents have not indicated their gender, there are more boys than girls. Once the datafile will be entirely completed, it will be possible to allocate these 400 questionnaires to one or the other gender, using a set of variables specific to boys and girls respectively (Jeannin et al. 2005).

\section{Discussion}

This paper demonstrates that it is possible to set-up a large national survey with minimal prerequisite local experience in the field and minimal financial coverage in an underprivileged Eastern European country. Several strategic issues have been

${ }^{1}$ Some 1000 more questionnaires have still to be put on the datafile.
Table 2 Socio-demographic characteristics of the sample, compared with some data from the Georgian 2000 census*

\begin{tabular}{|c|c|c|c|c|}
\hline & $\begin{array}{l}\text { girls (\%) } \\
n=4427\end{array}$ & $\begin{array}{l}\text { boys }(\%) \\
n=3184\end{array}$ & $\begin{array}{l}\text { total }(\%) \\
n=8039\end{array}$ & $\begin{array}{l}\text { Georgian } \\
\text { census }\end{array}$ \\
\hline \multicolumn{5}{|l|}{ Age } \\
\hline 13 & 1.2 & 1.1 & 1.1 & NA \\
\hline 14 & 14.4 & 13.7 & 13.8 & NA \\
\hline 15 & 34.6 & 33.5 & 33.7 & NA \\
\hline 16 & 30.4 & 31.2 & 30.3 & NA \\
\hline 17 & 16.4 & 16.2 & 16.1 & NA \\
\hline 18 & 1.6 & 1.9 & 1.7 & NA \\
\hline 19 & 0 & 0.1 & 0.1 & NA \\
\hline NR & 1.2 & 2.1 & 3.1 & NA \\
\hline \multicolumn{5}{|l|}{ Nationality } \\
\hline Georgian & 77.4 & 71.8 & 74.1 & 83.8 \\
\hline Abkhazian & 0.1 & 0.3 & 0.2 & 0.1 \\
\hline Osetian & 0.9 & 0.5 & 0.7 & 0.9 \\
\hline Russian & 1.3 & 1.2 & 1.2 & 1.5 \\
\hline Armenian & 10.3 & 8.7 & 9.7 & 5.7 \\
\hline Azeri & 7.3 & 12.5 & 9.2 & 6.5 \\
\hline Ukrainian & 0.3 & 0.3 & 0.3 & 0.2 \\
\hline Jewish & 0.1 & 0.2 & 0.2 & 0.1 \\
\hline Kurd & 0.4 & 0.6 & 0.5 & 0 \\
\hline Other & 0.4 & 0.6 & 0.5 & 1.2 \\
\hline NR & 1.5 & 3.3 & 3.4 & \\
\hline \multicolumn{5}{|l|}{ Residence } \\
\hline City & 69.2 & 64.3 & 65.7 & 53,2 \\
\hline Village & 28.4 & 31.7 & 29.7 & 46,7 \\
\hline NR & 2.3 & 4.1 & 4.6 & \\
\hline \multicolumn{5}{|l|}{ Parents' situation } \\
\hline live together & 83.5 & 83.5 & 82.7 & NA \\
\hline divorced or separated & 4.8 & 3.4 & 4.1 & NA \\
\hline father deceased & 6.6 & 5.9 & 6.2 & NA \\
\hline mother deceased & 1.0 & 0.8 & 0.9 & NA \\
\hline both parents deceased & 0.2 & 0.3 & 0.3 & NA \\
\hline other situation & 2.0 & 1.3 & 1.6 & NA \\
\hline NR & 2.0 & 4.8 & 4.1 & \\
\hline
\end{tabular}

* Adolescents aged 15 to 19: 177351 females, 179794 males. Around $8.16 \%$ of the total population identified during the design and implementation of this first Georgian country-based survey on adolescent health, which deserves consideration.

\section{Acceptance of the survey}

Two facets of the survey acceptance need to be distinguished. The first one concerns official administrative issues such as authorization and receiving legal permission to run the 
survey, as well as access to schools given by local authorities. In this survey, great care was taken to get authorization from all regions of Georgia, including Osetia and Abkhazia, despite the difficult political situation. One contributing factor to the final acceptance was a visit to Tbilisi of the head of the Lausanne team who was interviewed on the Georgian television about the importance and usefulness of a survey on adolescent health and life style and had several meetings with health authorities (Ministry of Labour, Health and Social Affairs, Medical University) and with physicians and medical students.

A second facet of acceptance deals with the adolescents themselves: how did they accept such "interest", "intrusion" or "concern" (as it was labeled in some of the comments by the pupils). During the Soviet era, epidemiological investigations were being carried out, but without any involvement of the target audience. Thus the Georgian team experienced for the first time the benefit of such kind of interactivity (e.g. focus group discussions with young people). Preliminary analyses of the available data show that, in rural areas, the frequency of refusal or non-responses was higher. The soviet system has not disappeared without traces, the Georgian society still remains a closed society, and its people, even the youth, don't believe wholeheartedly that confidentiality will be protected and thus are afraid to express their opinion, even anonymously. This is presumably a common problem for all post soviet countries.

About $5 \%$ of respondents in the first dataset wrote comments in the dedicated area of the questionnaire. Negative comments were very rare; comments mostly praised the usefulness of the questionnaire and expressed the wish that the experience would be reiterated in the future. Many pupils expressed positive feelings in having participated in such a study, and found rewarding that some people are interested in their health and in their opinion. They also expressed hope that this survey would contribute to improve adolescents' well-being.

Some children in their written comments have mentioned that they would have liked to have two different versions of the questionnaire, one for girls and one for boys, in order to avoid offending jokes. Other participants have found the number of questions overwhelming, which may be linked with the fact that they are not used to such questionnaires. These considerations underline the importance of preliminary discussions of the questionnaire content and survey procedure with young people. In this survey, this was done in focus groups, but only with adolescents from Tbilisi. It is thus advisable, when planning a survey in a country where it has not been done before, to carry out these pre-tests in all different regions involved, including rural areas.

\section{Cross-cultural issues}

Cross-cultural issues should not be underestimated (Alsacker et al. 1999): as already discussed, even after having gone through the process of acceptation of the questionnaire content by many instances and having discussed it appropriateness with young people, there were still regions were some items were ill accepted or raised concerns among the school authorities or the participants themselves. It also proved difficult to translate or adopt concepts directly from Switzerland to Georgia, such as training curricular, various kinds of youth groups, or issues such as sexual identity or contraception. It may well be that the wider and wider implementation of internet and dissemination of news from the West decreases the differences between adolescents from Eastern and Western countries, but it is still very important to involve representatives from various regional and social background in the preparation of the questionnaire, to avoid misunderstanding or rejection reactions (Michaud et al. 2001).

\section{Transfer of knowledge and experience}

One of the objectives of the studies undertaken within the SCOPES framework is to encourage the transfer of knowledge and experience from Western to Eastern European countries. We have identified some factors which contribute to this process. The ongoing communication allowed by email and PhProject was important, but still the visits of the team members in each other's settings were necessary to solve some difficult technical and administrative issues. The use of freeware or open-source software was also beneficial to the transfer of knowledge. It was possible to install these tools on as many computers as needed without cost consideration. In addition, it was very useful that PhProject performs well even with the slow phone connections typical to the post-soviet countries. Countries such as Georgia face difficult working conditions such as frequent electricity breakdowns which impeded data entry during several weeks, absence of heating during the cold months of the year, difficulties in reaching the remote districts, political tension and instability. There are several additional factors impeding scientific activity: limited access to the international scientific journals, insufficient involvement in the international network projects, language barrier, lingering effects of Soviet era's such as "strong" recommendations to first publish the results in Soviet periodicals and finally, notwithstanding a rapid expansion of internet over the country, a difficulty in being connected to Internet each time it is necessary.

In this study, the collaboration between a team with a strong background in survey research in the field of adolescent health and a local team mostly working in the clinical setting, with relatively limited experience in epidemiological or 
sociological research but with strong interests and motivation has been an inspiring and fruitful experience.

\section{Quality and security of the data}

One of the main concerns in the project was how to ensure the quality of the data in a situation where the local team had little experience on survey research and data processing, where local expertise on these matters was virtually non-existent and where material conditions were difficult (irregular power supply etc.). The features of EpiData pertaining to data entry quality and security worked out very well. Exporting the data was very easy and allowed to get a fully documented codebook and first overview of the results; the need for data cleaning once the data were transferred onto a SPSS datafile was also greatly reduced. The Lausanne team was very concerned about possible loss of data and stressed the need for regular backup of the data. In fact, thanks to the efforts of the local team, such a problem was not encountered.

\section{Public health concerns}

The Georgian Adolescent Health Survey takes place within an important effort that the health authorities and the Department of Paediatrics and Adolescent Medicine in Tbilisi have recently launched in order to improve the state of adolescent health in the country. In the longer term, the results of the survey will be exploited (as is the case in Switzerland (Michaud $2000 ; 2001)$ ) in the field of public health, which would hope- fully allow for an improvement in the health care delivery to teenagers and the building of effective preventive strategies. Also, it should incite the concerned authorities to launch effective training of professionals in the field of adolescent medicine.

On an international basis, the involvement of Georgian scientists in this collaborative project should facilitate their participation in the on-going European network of professionals working in this field. It is planned that the Tbilisi group would act as a platform for the development of adolescent health initiatives in some ex-Soviet Eastern European countries. Also, the final results will be discussed within the two research teams and should allow for interesting cross-cultural comparisons. Although it is often difficult to interpret crude variations in the rates of particular variables from one region/country to another, which may be due to translation or discrepancies in perceptions and interpretation of the question rather than real differences, the Georgian Adolescent Health Survey should help in shedding light on the type of factors involved in certain behaviours or health problems in both countries and thus, within the limits imposed by cross-sectional data, further the thinking on the association of specific personal and environmental traits with some health issues.

\section{Acknowledgement}

This project is sponsored by the Swiss National Science Foundation, SCOPES 7GEPj065646.

\section{Zusammenfassung}

Die Gesundheitsbefragung von Jugendlichen in Georgien: methodologische und strategische Fragen

Fragestellung: Um eine nationale Studie über Gesundheitszustand und Lebensstils von Jugendlichen in Georgien durchzuführen und dann eine Datenbasis über Jugendliche zu erstellen.

Methoden: Ein Kollektiv von insgesamt 8000-10000 Schülern von 15-18 Jahren wurde aus zufällig ausgewählten Schulklassen aus ganz Georgien bestimmt. Die Stichprobe wurde bezüglich Alter, Region, Typ der Schule und Sprache untersucht. Ein anonymisierter, selbst auszufüllender Fragebogen mit 87 Fragen, in die vier georgischen Unterrichtssprachen übersetzt, wurde als Arbeitsgrundlage verwendet.
Ergebnisse: Bis Juni 2004 konnten 511 (9306 Schüler) der 599 ausgewählten Klassen einbezogen werden. Insgesamt können 8039 Fragebögen als auswertbar betrachtet werden. Die Hauptprobleme stellten die Akzeptanz der Befragung, transkulturelle Fragen, politische wie strategische Hindernisse sowie die ungünstiges Klima.

Schlussfolgerungen: Trotz der ökonomisch und politisch ungünstigen Situation in Georgien war es möglich, eine nationale Studie über den Gesundheitszustand der Jugendlichen durchzuführen, welche den üblichen Qualitätsansprüchen gerecht wird. Diese Studie sollte, 1) die Prioritäten in der Gesundheitsversorgung und -förderung zu identifizieren und 2) die künftige Monitoring der Gesundheit der Jugendlichen erlauben. 
Résumé

\section{Enquête sur la santé des adolescents Géorgiens: questions} méthodologiques et stratégiques

Objectifs: Mener une enquête nationale sur la santé et les styles de vie des adolescents de Géorgie. Créer une banque de données permettant 1) la création de services de soins et d'interventions préventives efficaces; 2 ) le monitorage de la santé des jeunes.

Méthodes: Un échantillon aléatoire en grappe de 8 à 10000 élèves âgés de 15 à 18 ans a été tiré parmi toutes les classes du pays accueillant des élèves de cette tranche d'âge. L'échantillon a été stratifié par âge, région, type d'école et langue parlée. Un questionnaire auto-administré et anonyme de 87 questions, traduites en quatre langues, a été utilisé.
Résultats: Jusqu'en juin 2004, 511 classes (9306 élèves) ont été rencontrées. Le nombre de questionnaires valides est de 8039 . Les problèmes principaux rencontrés pour cette étude sont liés à son acceptation, à des problématiques trans-culturelles, à des barrières d'ordre politique et stratégiques, ainsi qu'à un environnement physique peu favorable.

Conclusions: En dépit de conditions économiques et politiques très défavorables en Géorgie, il a été possible de mener une recherche nationale sur la santé des adolescents répondants aux critères de qualité habituels. Cette recherche sera utilisée pour sensibiliser les autorités et les professionnels impliqués dans les activités de soins et de prévention destinées à cette classe d'âge.

\section{References}

Alsacker F, Flanagan C, Csapó B (1999). Methological challenges in cross-national research: countries, participants, and general procedures. In: Alsacker F, Flammer A, eds. The adolescent experience. London: Mahwah \& L. Erlbaum.

Arènes J, Janvrin M, Baudier F (1998). Baromètre santé- jeunes 97/98. Paris: Comité Français d'éducation pour la santé.

Bennett S, Myatt M, Jolley D, Radalowicz A (2004). Data management for surveys and trials: a practical primer using Epi Info. Llanidloes: Brixton Books.

Choquet M, Askevis M, Manfredi R, Ledoux S (1992). Les adolescents face aux soins: la consultation, l'hospitalisation. Paris: Ministère des affaires sociales et de l'intégration, INSERM.

Choquet M, Ledoux S (1993). Adolescents: enquête nationale: analyses et prospectives. Paris: Editions INSERM.

Choquet M, Ledoux $S$ (1994). Adolescents: enquête nationale. Paris: INSERM.

Coughlin S, Beauchamp T (1992). Ethics, scientific validity, and the design of epidemiologic studies. Epidemiology 3: 343-7.
Currie C, Roberts C, Morgan A, et al., V. (2004) Young people's health in context: Health Behaviour in School-aged Children (HBSC) study: international report from the 2001/2002 survey. Copenhagen: World Health Organisation.

Jeannin A, Narring F, Tschumper AM, et al. (2005). Self-reported needs and use of primary health care services by adolescents enrolled in post mandatory schools or vocational training programs in Switzerland. Swiss Med Weekly 135: 11-8.

Lothen-Kline C, Howard D, Hamburger E, Worrell K, Boekeloo B (2003). Truth and consequences: ethics, confidentiality, and disclosure in adolescent longitudinal prevention research. J Adol Health 33: 385-94.

Michaud PA (2000). La recherche en santé publique et les programmes de prévention: mariage impossible ? Rev Med Suisse Romande 120: 821-6.

Michaud PA (2001). La recherche rend-elle la prévention efficace ? L'exemple des adolescents. Dépendances 14: 8-12.

Michaud PA, Blum R, Slap G (2001). Crosscultural surveys of adolescent health and behaviour: progress and problems. Soc Sci Med 53: 1237-46.

Michaud PA, Stronski S, Fonseca H, Macfarlane A (2004). The development and pilot testing of a training curriculum in adolescent medicine and health. J Adol Health 35: 51-7.
Miller D (1991). Handbook of research design and social measurement. London: Sage.

Narring F, Michaud PA (1995). Methodological issues in adolescent health surveys: the case of the Swiss multicenteradolescent survey on health. Soz Praventiv Med 40: 172-82.

Narring F, Tschumper A, Inderwildi Bonivento $L$, et al. (2003). Santé et styles de vie des adolescents âgés de 16 à 20 ans en Suisse: SMASH 2002. Lausanne: Institut universitaire de médecine sociale et préventive.

Narring F, Tschumper A, Michaud P, Vanetta F, Meyer R, Wydler H (1994). La santé des adolescents en Suisse: rapport d'une enquête nationale sur la santé et les styles de vie des 15-20 ans. Lausanne: Institut universitaire de médecine sociale et préventive.

Pagava K (2004). Adolescents health in Georgia (state of art review ). Georgian Medical News 114: 51-4.

Pagava K, Gachechiladze T, Sikharulidze A (2001). Methodological approaches to the systemic analysis of the health and behavior of adolescents. Georgian Medical News 70: 39-40.

Resnick MD, Bearman PS, Blum RW, Bauman KE, Haris KM, Jones J (1997). Protecting adolescents from harm: findings from the National Longitudinal Study on Adolescent Health. JAMA 278: 823-32. 
Schmid H (2003). Evolution de la consommation de substances psychotropes chez les écolières et les écoliers en Suisse. Lausanne: Institut Suisse de prévention de l'alcoolisme et autres toxicomanies.

Sonquist J, Dunkelberg W (1977). Survey and opinion research: procedures for processing and analysis. Englewood Cliffs, NJ: Prentice-Hall.

Spruijt-Metz D (1999). Adolescence, affect and health: adolescents> perceptions and participation in survey research. Hove, UK: Psychology Press.
Statistics Canada (1996). Census dictionary: final edition, Appendix O: Data quality, sampling and weighting, confidentiality and random rounding. Ottawa: Statistics Canada.

Zimmer-Gembeck MJ, Alexander T, Nystrom RJ (1997). Adolescents report their need for and use of health care services. J Adol Health 21: 388-99.
Address for correspondence

Prof. P.-A. Michaud

UMSA

CHUV

CH-1011 Lausanne

Tel.: +41 213143760

Fax: +41 213143769

e-mail: Pierre-

Andre.Michaud@hospvd.ch 